\title{
PERBEDAAN PENGARUH MODEL PEMBELAJARAN GIPS (GUIDED INQUIRY PROBLEM SOLVING) DAN PLGI (PEER LED GUIDED INQUIRY) TERHADAP PRESTASI BELAJAR KIMIA DITINJAU DARI KEMAMPUAN ANALISIS PADA MATERI HIDROLISIS KELAS XI IPA SMA N 1 SRAGEN TAHUN PELAJARAN 2017/2018
}

\author{
Ary Eny Lestari, Endang Susilowati ${ }^{\star}$, dan Bakti Mulyani \\ Program Studi Pendidikan Kimia, FKIP, Universitas Sebelas Maret, Surakarta, Indonesia
}

Keperluan korespondensi, HP: +6281548553791, email: endwati@staff.uns.ac.id

\begin{abstract}
ABSTRAK
Penelitian ini bertujuan untuk mengetahui: (1) pengaruh pembelajaran model PLGI dan GIPS terhadap prestasi belajar siswa, (2) pengaruh kemampuan analisis terhadap prestasi belajar siswa , (3) Interaksi pembelajaran dengan model GIPS dan PLGI ditinjau dari kemampuan analisi terhadap prestasi belajar.Penelitian ini menggunakan metode komparasi yang membandingkan antara dua model yaitu GIPS dan PLGI yang ditinjau dari kemampuan analisis, menggunakan desain faktorial 2X2. Subjek penelitian adalah siswa kelas XI MIPA 4 dan XI MIPA 5 yang diambil menggunakan teknik cluster random sampling. Kelas XI MIPA 4 diberikan model pembelajaran PLGI sedangkan kelas XI MIPA 5 diberikan model pembelajaran GIPS. Data prestasi pengetahuan dan kemampuan analisis diperoleh melaui tes, data prestasi sikap melalui angket dan observasi, dan data prestasi keterampilan diperoleh melalui observasi. Analisis data pada penelitian ini menggunakan Analisis Varians dua jalan dan uji kruskal wallis. Hasil menununjukan: (1) terdapat pengeruh model pembelajaran PLGI dan GIPS terhadap prestasi belajar ranah pengetahuan,sikap dan keterampilan. (2) tidak terdapat pengaruh model pembelajaran PLGI dan GIPS terhadap ranah pengetahuan, sikap dan keterampilan.(3). Terdapat interaksi antara model pembelajaran PLGI dan GIPS ditinjau dari kemampuan analisis terhadap prestasi belajar ranah sikap dan keterampilan namun tidak terdapat interaksi untuk ranah pengetahuan.
\end{abstract}

Kata Kunci: GIPS, PLGI, Hidrolisis, kemampuan analisis dan prestasi belajar

\section{PENDAHULUAN}

Kunci utama bagi kemajuan dan keunggulan suatu bangsa adalah pendidikan. Mencerdaskan kehidupan bangsa merupakan salah satu tujuan dari bangsa Indonesia yang tertuang dalam pembukaan UUD 1945. Undang-Undang Nomor 20 Tahun 2003 mengenai sistem pendidikan Nasional menyatakan dalam pasal 1 ayat 1 menyatakan bahwa pendidikan adalah usaha sadar dan terencana untuk mewujudkan suasana belajar dan proses pembelajaran agar peserta didik secara aktif mengembangkan potensi dirinya untuk memiliki kekuatan spiritual keagamaan, pengendalian diri, kepribadian, kecerdasaan akhlak mulia, serta ketrampilan yang diperlukan dirinya, masyarakat, bangsa dan negara.

Seiring dengan perkembangan ilmu pengetahuan dan teknologi, pemerintah memberikan perhatian khusus dengan melakukan pembaharuan kurikulum. Kurikulum 2013 merupakan acuan dalam pendidikan Indonesia saat ini. Menurut Peraturan Menteri Pendidikan dan Kebudayaan Nomor 22 tahun 2016 tentang standar proses pendidikan dasar dan menengah menya- 
takan bahwa sesuai dengan Standar Kompetensi Lulusan (SKL) sasaran pembelajaran mencakup pengembangan ranah sikap, pengetahuan, dan keterampilan yang dielaborasi untuk setiap satuan pendidikan. Ketiga ranah kompetensi tersebut memiliki lintasan perolehan (proses psikologis) yang berbeda. Sikap diperoleh melalui aktivitas "menerima, menjalankan, menghargai menghayati dan mengamalkan. Pengetahuan di peroleh melalui aktivitas "mengingat, memahami, menerapkan, menganalisis, dan mengevaluasi.

Pada pembelajaran kurikulum 2013 siswa dituntut untuk mengembangkan kreativitas dan kemampuan analisisnya. Kurikulum 2013 menekankan pada pendekatan saintifik dengan menerapkan berbagai model pembelajaran Discovery, Inquiry, Problem Solving dan Project Based Learning. Pembelajaran kurikulum 2013 pembelajaran tidak didominasi oleh guru. Guru sebagai pendidik merupakan fasilitator dan menempatkan siswa sebagai subyek pembelajaran sehingga proses pembelajaran tidak berpusat pada guru (teacher center learning) namun berpusat pada siswa bersifat student center learning.

Kimia merupakan salah satu cabang dari ilmu pengetahuan alam yang merupakan mata pelajaran wajib pada satuan pendidikan sekolah menengah atas (SMA). Karakteristik ilmu kimia sebagai proses dan produk harus di perhatikan dalam pembelajaran dan penilaian hasil belajar kimia [1]. Perkembangan saat ini kimia dipandang sebagai ilmu yang diperoleh dan didasarkan berdasarkan teori (deduktif). Oleh sebab itu penalaran dan ketrampilan selalu dilibatkan dalam pembelajaran kimia. Terdapat dua hal yang tidak dapat terpisahkan dalam pembelajaran kimia yaitu kimia sebagai proses yaitu kerja ilmiah dan sebagai produk yaitu kimia sebagai fakta, konsep, prinsip, hukum dan teori.

Hidrolisis merupakan salah satu materi kimia yang membutuhkan kemampuan analisis data untuk membuktikan hipotesis yang dibuat siswa. Sehingga pembelajaran yang berpusat pada guru dirasa kurang efektif. Materi ini seharusnya memakai pembelajaran yang berpusat pada siswa yang aktif dan dapat mengkonstruksikan pengetahuan, sehingga didapat siswa yang memahami konsep-konsep secara jangka panjang bukan hanya menghafal.

Untuk mencapai tujuan proses belajar mengajar ditentukan oleh berbagai faktor baik eksternal maupun internal. Salah satu faktor eksternal yaitu pemilihan model pembelajaran yang sesuai dengan karakteristik materi dan siswa. Selain faktor eksternal faktor internal juga mempengaruhi proses pembelajran salah satunya adalah kemampuan siswa dalam menganalisis data untuk menguji hipotesis serta menyimpulkan hasil juga mempengaruhi keberhasilan proses belajar mengajar. Namun pada kenyataan seringkali siswa masih mengalami kesulitan pada proses menganalisis data yang diperoleh.

Materi hidrolisis garam merupakan salah satu materi pembelajaran kimia yang menuntut pemahaman konseptual dan algoritmik. Pemahaman konseptual dalam kimia mencakup kemampuan untuk memperesentasikan dan menerjemahkan masalah-masalah kimia dalam bentuk representasi makroskopik, mikroskopik, bentuk-bentuk gambaran simbolik seperti lambang, rumus, persamaan reaksi, grafik dan sebagainya [2].

Maka dari uraian permasalahan tersebut dibutuhkan pembelajaran yang mampu meningkatkan prestasi belajar siswa. Prestasi belajar memiliki korelasi positif dengan kemampuan analisis, sekitar $78,4 \%$, prestasi belajar siswa dipengaruhi kemampuan analisis [3]. Hal tersebut berarti salah satu faktor penting untuk meningkatkan prestasi belajar adalah kemampuan analisis.

Salah satu pembelajaran yang dapat membantu meningkatkan kemampuan analisis siswa adalah Guided Inquiry (GI). Triyanto menyatakan bahwa Guided Inquiry berarti suatu rangkaian kegiatan belajar yang melibatkan secara maksimum seluruh kemampuan siswa untuk mencari dan menyelidiki secara sistematis. Keterlibatan siswa secara maksimal dalam pembelajaran Guided Inquiry dalam pembelajaran, keterarahan dalam berpikir logis dan sistematis dalam 
proses inquiry [4]. Sehingga dapat disimpulkan bahwa pembelajaran Guided Inquiry dapat membantu siswa mengkonstruk pemahaman konsep dalam materi hidrolisis.

Salah satu model pembelajaran yang cocok untuk diintegrasikan dengan Guided Inquiry adalah model problem solving. Problem solving merupakan model berbasis masalah untuk diterapkan dalam kehidupan sehari-hari [5]. Selain itu model problem solving juga dapat menumbuhkan sikap percaya diri dan kemandirian dengan menyusun pengetahuan secara bermakna.

Berdasarkan hal tersebut maka peneliti menggunakan model pembelajaran GIPS yang diharapkan mampu untuk meningkatkan prestasi belajar dan kemampuan analisis. GIPS merupakan kombinasi yang dapat meningkatkan kemampuan berpikir kritis siswa, hal ini dikareankan pada model pembelajaran Guided Inquiry siswa dapat mengkonstruksi pengetahuan melalui eksperimen, proses berpikir dan bertanya, dan dengan problem solving siswa menjadi lebih aktif dan mampu berpikir memecahkan masalah [6].

Selain model GIPS, terdapat model pembelajaran lain yaitu PLGI. Model ini merupakan inquiry terbimbing dengan modifikasi teman sejawat sebagai tutor. Jika pada model pembelajaran GIPS masih didominasi oleh guru dalam memberikan rangsangan, pada pembelajaran PLGI siswa lebih dilibatkan dalam proses pembelajaran [7]. Model PLGI merupakan perpaduan antara inkuiri terbimbing dengan pembelajaran kooperatif tutor sebaya. [8].

\section{METODE PENELITIAN}

Penelitian ini merupakan penelitian kuasi eksperimen. Teknik pengambilan sampel pada penelitian ini menggunakan teknik cluster random sampling. Sampel dalam penelitian ini adalah siswa kelas XI MIPA 4 dan XI MIPA 5 SMAN1 Sragen.

Teknik pengumpulan data dalam penelitian ini dilakukan dengan menggunakan beberapa tes pada prestasi belajar pengetahuan dan kemampuan analisis menggunkan tes sedangkan pada ranah sikap menggunakan angket dan observasi, dan pada ranah keterampilan menggunakan observasi.

\section{HASIL DAN PEMBAHASAN}

Data pada penelitian ini meliputi skor kemampuan analisis dan prestasi belajar sisiwa. Kelas XI MIPA 5 menggunakan model GIPS sedangkan pada XI MIPA 4 menggunakan model PLGI. Masing-masing dari kelas tersebut memiliki jumlah siswa 32 siswa.

Pada penelitian ini uji prasyarat analisis menggunakan uji normalitas dengan software SPSS 23, didapat hasil bahwa data penelitian merupakan data non parametrik. Hal ini dikarenakan beberapa data terdistribusi tidak normal.

Selanjutnya uji hipotesis dilakukan menggunakan software SPSS dengan uji non para materik Kruskal wallis, hasil uji hipotesis kruskal wallis dapat dilihat pada tabel 1.

Tabel 1 hasil uji Hipotesis Kruskal Wallis

\begin{tabular}{cccc}
\hline Hipo- & \multicolumn{3}{c}{ Signifikansi } \\
\cline { 2 - 4 } tesis & $\begin{array}{c}\text { Pengeta- } \\
\text { huan }\end{array}$ & Sikap & $\begin{array}{c}\text { Keteram- } \\
\text { pilan }\end{array}$ \\
\hline A & 0,330 & 0,000 & 0,011 \\
B & 0,585 & 0,155 & 0,081 \\
C & 0,199 & 0,001 & 0,036 \\
\hline
\end{tabular}

Tabel 2 menyatakan hasil dari uji hipotesis dengan kruskal wallis dimana menyatakan adanya pengaruh antara model PLGI dan GIPS terhadap prestasi belajar siswa, $\mathrm{B}$ menyatakan adanya pengaruh antara kemampuan analisis terhadap prestasi belajar dan $\mathrm{C}$ menyatakan adanya interaksi antara model pembelajaran PLGI dan GIPS dengan kemampuan analisis terhadap prestasi belajar siswa.

Uji Kruskal Wallis menunujukan jika signifikansi > 0,05 maka Ho diterima sehingga tidak terdapat pengaruh, sedangkan jika signifikan 0,005 maka Ho ditolak maka terdapat pengaruh.

\section{Pengujian Hipotesis Pertama}

\section{a. Ranah Pengetahuan}

Pada hipotesis pertama pada ranah pengetahuan menunujukan adanya pengaruh antara model pembelajaran 
PLGI dan GIPS terhadap prestasi ranah pengetahuan.

Model pembelajaran PLGI memiliki rata-rata yeng lebih tinggi daripada model GIPS, hal ini dikarenakan pada model pembelajaran PLGI siswa cenderung lebih aktif berdiskusi dan bertanya. Siswa lebih mengembangkan kemampuan berdiskusi dan bertanya karena telah terlebih dahulu mendapat arahan dari tutor sebaya. Model ini juga dimungkinkan dapat menambah rasa percaya diri pada siswa. Hal ini sesuai dengan penelitian Lailatun dan Mahdian (2017) bahwa model pembelajaran PLGI pada materi Hidrolisis dapat meningkatkan hasil belajar kognitif.

Dalam model pembelajaran GIPS setelah guru menyampaikan konsep dan apersepsi materi Hidrolisis dengan cara menghubungkan dengan kehidupan sehari-hari. Selanjutnya siswa diberi LKS untuk merumuskan masalah. Setelah itu siswa harus membuat hipotesis dari permasalahan tersebut. Setealah itu siswa mengumpulkan data dari kegiatan praktikum, buku dan internet. Selanjutnya siswa menganalisis data tersebut dan menguji hipotesis. Setalah itu siswa membuat kesimpulan berdasarkan analisis data dan hipotesis yang telah mereka buat. Siswa mempresentasikan kesimpulan selanjunya jika terdapat perbedaan antara hipotesis, maka kelompok lain dapat menyanggah atau menguatkan konsep dari siswa. Secara umum dalam setiap pertemuan siswa masih malu untuk menyanggah atau menguatkan konsep dari teman. Metode ini menyebabkan siswa yang terlibat aktif hanya siswa-siswa tertentu saja, terlihat masih banyak siswa yang masih pasif untuk bertanya [6]. Hal inilah yang menjadi kekurangan dari model GIPS.

Sedangkan dalam model pembelajaran PLGI, setalah guru membagi siswa menjadi 8 kelompok dan memilih satu orang dari masing-masing kelompok sebagai tutor sebaya. Langkah selanjutnya sama seperti pada model GIPS yaitu merumuskan masalah, membuat hipotesis, mengumpulkan data, menganalisis data dan membuat kesimpulan.

Langkah terakhir hanya membuat kesimpulan tanpa manganalisis perbeda- an hipotesis antar kelompok. Model ini siswa cenderung aktif berdiskusi. Selain itu siswa juga mengerti rumusan masalah awal karena teman mereka sendiri yang menjelaskan. Terdapat perbedaan dalam merumuskan masalah jika pada model GIPS dibantu oleh guru sedangkan pada model PLGl dibantu oleh siswa tutor sebaya. Tutor sebaya sebelum memulai pembelajaran juga sudah diberi arahan kepada guru sehingga proses pembelajaran semakin berjalan dengan baik. Hal ini dimaksudkan agar pembelajaran lebih efektif [9]. Walaupun kondisi kelas gaduh dan ramai namun hal tersebut dikarenakan siswa aktif diskusi dengan bimbingan tutor sebaya. Keuntungan dari model ini siswa sangat terbantu dengan tutor sebaya karena siswa tidak malu dan mengerti penjelasan dari tutor, hal ini dimungkinkan karena Bahasa yang mereka gunakan lebih mudah dipahami berbeda jika dengan guru.

Hal ini didukung dengan penelitian sebelumnya yang menyatakan bahwa peer Led (teman sejawat) dapat melibatkan keaktifan siswa dalam proses pembelajaran [10]. Pembelajaran PLGI juga dapat memaksimalkan penguasaan konsep pada siswa [11]. Hal tersebut juga dipengaruhi oleh diskusi teman sejawat yang memebentuk lingkungan belajar yang kaya akan diskusi yang mampu mengembangkan kemampuan berpikir kritis dan penguasaan konsep [12]. Sehingga pembelajaran berbasis teman sejawat lebih baik daripada pembelajaran diskusi kelas [13].

\section{b. Ranah Sikap}

Hasil dari tabel 2 menunujukan terdapat pengaruh model pembelajaran GIPS dan PLGI terhadap prestasi belajar ranah sikap siswa pada materi garam hidrolisis. Salah satu aspek yang mempngaruhi adanya pengaruh antara model dan hasil belajar ranah sikap adalah adanya hubungan antara indikator penilaian ranah sikap dengan sintaks model pembelajaran. terdapat 4 indikator sosial yang mempengaruhi penilaian ranah sikap yaitu sikap jujur, disiplin, tanggung jawab dan percaya diri. Terdapat perbedaan sintaks antaar 
kedua model yang, pada sintaks merumuskan masalah, membuat hipotesis, mengumpulkan data, menganalisis data dan membuat kesimpulan hal tersebut relevan dengan indikator ranah sikap jujur, didiplin dan tanggung jawab. Akan tetapi pada model GIPS terdapat satu sintak yang tidak terdapat pada PLGI namun relevan dengan indikator percaya diri yaitu pada sintaks mengevaluasi argumen dan hipotesis yang berbeda anatar kelompok. Hal ini yang mempengaruhi model GIPS mendapat rata-rata yang lebih tinggi daripada PLGI.

Berdasarkan penelitian terdahulu maka dapat disimpulkan bahwa siswa dengan kelas inkuiri terbimbing dengan model yang belum pernah mereka alami akan memeberikan dampak positif dalam keaktifan memecahkan masalah. Sehingga memudahkan siswa dalam membangun pengetahuan yang akan berdampak pada peningkatan kepercayaan diri sehingga mengakibatkan prestasi belajar ranah sikap akan meningkat [14].

Pada dasarnya model pembelajaran Guided Inquiry akan memberikan pengaruh pada prestasi belajar ranah sikap, hal ini sejalan dengan penelitian sebelumnya yaitu adanya pengaruh model Guided Inqury dengan berbantuan LKS bebas dan LKS terhadap prestasi belajar ranah sikap [15]. Hal tersebut juga sejalan dengan penelitian terdahulu, pembelajaran dengan menggunakan model CPS (Cooperative Problem Solving) mamapu meningkatkan prestasi belajar siswa ranah sikap daripada model pembelajaran SSCS (Search Solve Create and Share) [16]. Hal ini sejalan dengan hasil penelitian, dikarenakan model SSCS memiliki sintaks yang hampir sama dengan model GIPS.

\section{c. Ranah Keterampilan}

Hasil dari Kruskal Wallis pada aspek ranah keterampilan menunujukan terdapat pengaruh model pembelajaran GIPS dan PLGI terhadap prestasi belajar ranah keterampilan siswa pada materi garam hidrolisis. Aspek Ketrampilan pada materi Hidrolisis berhubungan dengan ketrampilan tangan (hand on activity ) siswa untuk mencapai tujuan pembelajaran pada kegiatan percobaan kimia di laboratorium. Hasil prestasi belajar ranah keterampilan didapat dari kegiatan praktikum siswa dengan yang bersumber dari penilaian observasi. Praktikum hanya dilakukan pada pertemuan pertama, untuk pertemuan kedua dan ketiga siswa mengumpulkan dan menganalisis data yang berasal dari sumber belajar.

Hal tersebut sesuai dengan penelitian yang menyatakan bahwa pembelajaran dengan praktikum meningkatkan kualitas pengetahuan siswa [17]. Hasil penelitian relevan dengan penelitin sebelumnya yaitu terdapat pengaruh antara kelas model eksperimen dan Guided Inquiry terhadap nilai rata-rata ranah keterampilan. Model pembelajaran Guided Inquiry dapat memberikan dampak dapat meningkatkan minat dan keinginan siswa untuk berhasil. Hal tersebut akan mendorong kinerja ssiwa untuk lebih terampil menggunakan alatalat praktikum [14]. Penelitian lain mengemukakan bahwa model SSCS dan CPS memberikan pengaruh pada ranah keterampilan, dimana model CPS lebih bagus dari pada model SSC [16]. Model pembelajaran dengan menggunakan eksperimen di laboratorium membutuhkan kerjasama antar kelompok sehingga siswa akan lebih terampil dalam melakukan praktikum [18]. Penelitian serupa juga menunujukan adanay pengeruh model Guided Inquiry berbentuan LKS bebas termodifikasi dan terbimbing dapat berpengaruh terhadap ranah keterampilan [15].

\section{Pengujian Hipotesis Kedua}

\section{a. Ranah Pengetahuan}

Hasil dari Uji Kruskal Wallis pada prestasi belajar siswa ranah pengetahuan menunujukan tidak terdapat pengaruh antara kemampuan analisis siswa kategori tinggi dan rendah terhadap prestasi belajar kognitif siswa pada materi Hidrolisis.

Kemampuan analisis merupakan bagian dari kemampuan berpikir kritis, kegagalan dalam berpikir kritis dapat menyebabkan kegagalan dalam bidang 
akademik [19]. Selain itu kemampuan analisis siswa akan berbanding lurus dengan hasil belajar, siswa dengan kemampuan analisis tinggi hasil belajar kimianya akan lebih baik akan berlaku sebaliknya pada siswa yang memiliki kemampuan analisis rendah [20]. Hal tersebut tidak sesaui dengan hipotesis pada penelitian ini.

Hal ini dikarenakan terdapat enam tingkatan dengan aspek belajar berbeda pada kemampuan kognitif, yaitu tingkat pengetahuan, pemahaman, penerapan analisis, sintesis, evaluasi [21]. Dapat disimpulkan bahwa walaupun kemampuan analisis merupakan tingkatan aspek belajar dalam kemampuan ranah pengetahuan, namun masih terdapat tingkatan yang lain. Hal ini dimungkinkan siswa dari kedua model belum sampai pada tingkatan analisis pada aspek belajar sehingga kemampuan analisis tidak memepengaruhi kemampuan kognitif siswa.

Hal tersebut juga dikarenakan dari 5 indikator kemampuan analisis hanya 2 indikator yang mewakili soal pada materi hidrolisis [22]. Indikator tersebut adalah menginterpretasikan informasi secara akurat, mengidentifikasi adanya ketidak konsistenana informasi untuk memecahkan masalah, dan memilih hipotesis dari suatu kajian teori. Ketiga indikator tersebut tidak memberikan andil yang pada soal hidrolisis kemampuan ranah pengetahuan. Namun untuk indikator seperti menginterpretasi informasi dari suatu tabel atau data secara akurat hal ini sesuai dengan indikator soal hidrolisis untuk membedakan sifat-sifat larutan pada garam hidrolisis. Hal serupa juga pada indikator menghubungkan keterkaitan antara anatar hal atau bagian konsep hal ini sesuai dengan indikator memeperkirakan garam yang dapat terhidrolisis secara total, sebagian atau tidak terhidrolisis.

\section{b. Ranah Sikap}

Hasil dari uji non-parametrik pada ranah sikap menunujukan tidak terdapat pengaruh antara kemampuan analisis siswa kategori tinggi dan rendah terhadap prestasi belajar ranah sikap siswa pada materi Hidrolisis.
Berdasarkan data tersebut, hal ini dikarenakan tidak terdapat hubungan antara indikator kemapuan analisis dan indikator penilaian ranah sikap. Sehingga tidak terdapat pengaruh antara kemampuan analisis dengan prestasi belajar ranah sikap. Hal ini sejalan dengan penelitian bahwa perubahan afektif tidak terjadi serta merta tetapi melalui proses yang membutuhkan waktu yang lebih lama daripada aspek kognitif dan dukungan dari lingkungan [23].

Hal ini sejalan dengan penelitian sebelumnya yang menyatakan bahwa tidak adanya pengaruh siswa yang memiliki kemampuan berpikir kritis tinggi dan rebdah terhadap prestasi belajar ranah sikap, kemampuan analisis juga merupakan bagian dari kemampuan berpikir kritis [16]. Penelitian lain juga menunujukan bahwa faktor kemampuan analisis tidak memiliki pengaruh pada hasil belajar rahnah sikap [24].

\section{c. Ranah Keterampilan}

Hasil dari uji Kruskal Wallis tabel 2 pada aspek keterampilan menunujukan tidak terdapat pengaruh antara kemampuan analisis siswa kategori tinggi dan rendah terhadap prestasi belajar ranah keterampilan siswa pada materi Hidrolisis.

Salah satu faktor internal yang memepengaruhi prestasi psikomotor yaitu kemampuan analisis. Siswa akan menganalisis data praktikum, kesalahan dalam menggunakan alat dan perbedaan antara hipotesis diperlukan kemampuan analisis. Kemampuan analisis digunakan dalam materi Hidrolisis yaitu dalam menganalisis jenis dan sifat garamgaram Hidrolisis, sehingga siswa dapat menggolongkan garam yang bersifat basa, asam dan netral.

Namun pada kenyataanya, kemampuan analisis tidak memberikan pengaruh terhadap prestasi psikomotor pada materi Hidrolisis. Hal ini dikarenakan tidak terdapat hubungan anatara indikator penilaian prestasi belajar ranah keterampilan dan inidikator penilaian kemampuan analisis. Sehingga pengaruh kemampuan analisis tidak signifikan.

Hal ini sesuai dengan penelitian sebelumnya yang menyatakan bahwa 
tidak adanya pengaruh faktor kemampuan berpikir kritis pada prestasi belajar ranah keterampilan [16]. Kemampuan analisis masih merupakan bagian kemampuan berpikir kritis sehingga dapat disimpulkan bahwa prestasi belajar ranah keterampilan tidak memiliki pengaruh pada penilaian prestasi belajar ranah keterampilan. Hal ini juga sejalan dengan penelitian pada materi hidrolisis kemampuan analisis tidak memiliki pengaruh terhadap prestasi belajar ranah keterampilan [24].

\section{Pengujian Hipotesis Ketiga}

\section{a. Ranah Pengetahuan}

Hasil dari uji Kruskal Wallis menujukan bahwa tidak terdapat interaksi antara model pembelajaran PLGI dan GIPS dengana kemampuan analisis terhadap prestasi siswa ranah pengetahuan pada materi hidrolisis garam. Hal ini disebabkan karena berbagai faktor yeng memiliki pengaruh pada proses pencapaian kognitif baik dari dalam maupun luar diri siswa disamping faktor model pembelajaran dan kemampuan analisis yang digunakan dalam penelitian.

Antara kemampuan analisis dan prestasi model pembelajaran tidak memberikan efek yang signifikan terhadap prestasi belajar ranah pengetahuan. Penelitian lain juga ditemukan bahwa tidak adanya interaksi anatar penggunaan pendekatan pembelajaran metode inkuiri berbasis motode eksperimen dan demonstrasi dengan kemamapuan analisis terhadap hasil belajar ranah pengetahuan [25].

Meskipun hasil analisis didapatkan tidak adanya interaksi, namun siswa pada model pembelajaran PLGI lebih baik daripada GIPS. Hal ini karena siswa dengan model PLGI memiliki nilai hasil belajar ranah penegtahuan lebih besar daripada GIPS. Hal ini menunujukan bahwa kedua model memiliki pengaruh terhadap hasil belajar ranah pengetahuan, walaupun berasal dari metode yang sama yaitu Guided Inquiry. Karena tidak semua model memiliki interaksi antara kemampuan analisis terhadap prestasi belajar. Dimungkinkan masih banyak kemampuan internal lain dalam diri siswa yang mempengaruhi, seperti berpikir logis, rasa ingin tahu dan kemampuan matematis [26]. Hal ini sejalan dengan penelitian sebelumnya, yaitu tidak adanya interaksi antara pembelajaran learning cycle 7E dan guided inquiry dengan kemampuan berpikir kritis terhadap perstasi belajar siswa ranah pengetahuan [27].

\section{b. Ranah Sikap}

Berdasarkan tabel 2 maka dapat diseimpulkan bahwa terdapat pengaruh interaksi antara pembelajaran model PLGI dan GIPS dengan kemampuan analisis terhadap prestasi belajar afektif siswa pada materi Hidrolisis garam.

Hipotesis pertama menunujukan bahwa model PLGI dan GIPS memiliki pengaruh terhadap prestasi belajar siswa ranah sikap pada materi Hidrolisis. Hal ini tidak sejalan dengan hasil uji kruskal wallis untuk hipotesis kedua yaitu tidak adanya pengaruh kemampuan analisis terhadap prestasi belajar ranah sikap. Adanya interaksi antara model pembelajaran PLGI dan GIPS dengan kemampuan analisis terhadap prestasi belajar afektif siswa pada materi Hidrolisis, hal ini menunjukan adanya efek kemampuan analisis sebagai salah satu faktor internal pada penggunaan model PLGI dan GIPS terhadap prestasi belajar afektif siswa pada materi hidrolisis. Kemampuan analisis menjadi faktor penentu prestasi belajar afektif siswa pada penggunaan model pembelajaran PLGI dan GIPS.

Hal ini sejalan dengan penelitian terdahulu bahwa adanya interaksi pengunaan model inkuiri terbimbing dan POGIL dengan kemampuan analisis terhadap prestasi belajar siswa ranah sikap, hal ini dikarenakan dengan adanya dukungan kemampuan analisis yang dimiliki siswa maka akan bedampak pada bertambahnya kepercayaan diri siswa [22]. Selain itu pada penelitian lain juga menunujukan adanya interaksi model pembelajaran Guided Inquiry menggunkan LKS terbimbing dan bebas termodifikasi dengan kreativitas dan motivasi terhadap prestasi belajar ranah sikap [15]. Penelitian lain juga 
menunjukkan bahwa model pembelajaran Guided Inquiry memberikan dampak pada peningkatan pemahaman sains yang akan membentuk sikap meliputi karakter (jujur, teliti tanggung jawab dan menghargai orang lain), keterampilan sosial kerja sama sesama teman [28].

\section{c. Ranah Keterampilan}

Berdasakan uji Kruskal wallistabel 2 menunujukan bahwa terdapat interaksi antar model pembelajaran GIPS dan PLGI dengan kemampuan analisis terhadap prestasi belajar ranah keterampilan.

Hal ini dikarenakan dari segi perencanaan pembelajaran yang dapat menghadirkan lingkungan kelas yang dapat meningkatkan siswa untuk bertindak positif dan minat untuk mengikuti proses pembelajaran [30]. Selain itu pada penelitian lain juga menyatakan bahwa terdapat interaksi antara penggunaan metode eksperimen dan guided inquiry dengan kemampuan matematis terhadap prestasi belajar ranah psikomotor, siswa memiliki keterampilan psikomotor yang baik karena siswa memiliki kebebasan jika menggunakan model guided inquiry. Keinginan siswa yang kuat untuk berhasil pada percobaan juga mendorong kinerja di laboratorium sehingga lebih berhati-hati dan optimal [14].

\section{KESIMPULAN}

Berdasarkan hasil penelitian yang telah dilakukan, maka dapat disimpulkan bahwa Terdapat pengaruh model pembelajaran PLGI dan GIPS terhadap prestasi belajar ranah pengetahuan, sikap, dan keterampilan siswa. Tidak terdapat pengaruh kemampuan analisis siswa pada kategori tinggi dan rendah terhadap prestasi belajar ranah pengetahuan, sikap dan keterampilan siswa pada materi Hidrolisis. Tidak ada interaksi antara model pembelajaran PLGI dan GIPS dengan kemampuan analisis siswa terhadap prestasi belajar ranah pengetahuan namun terdapat interaksi antara model pembelajaran PLGI dan GIPS dengan kemampuan analisis siswa terhadap prestasi belajar ranah sikap dan keterampilan siswa pada materi Hidrolisis.

\section{UCAPAN TERIMA KASIH}

Ucapan terima kasih penulis haturkan kepada seluruh pihak yang telah membantu dalam penelitian ini, khususnya kepada Ibu Aisatul Laila, S.Pd.,. selaku guru kimia kelas XI MIPA dan XI MIPA 5 SMA N 1 Sragen yang telah berkenan bekerja sama serta memberikan izinnya sehingga penulis dapat melakukan penelitian di kelas yang beliau ampu. Tak lupa juga terima kasih untuk siswa-siswa kelas XI MIPA 4 dan XI MIPA 5 SMAN 1 Sragen yang telah membantu dalam penelitian ini.

\section{DAFTAR RUJUKAN}

[1] Mulyasa. (2007). Kurikulum Tingkat Satuan Pendidikan. Bandung : Remaja Rodakarya .

[2] Faizah, A. S. (2013). Studi Pemahaman Konsep Tata Nama IUPAC Senyawa Anorganik Siswa Kelas X SMAN 2 Malang Semester 2 Tahun Ajaran 2012/2013. Malang : Universitas Negeri Malang.

[3] H Bayram, C. A. (2009). Examining the Realtions between Science Attitudes, Logical Thingking Ability, Information Literacy and Academic Achivent through Internet Assisted Chemistry Education. Procedia and behavioral Science, 15361532.

[4] Permana, N. N. (2014). Pengaruh Model Pembelajaran Inkuiri Terbimbing Berbantuan Media Grafis Terhadap Hasil Belajar Matematika Kelas IV SD Gugus 4 Kecamatan Busunghui. Jurnal Mimbar PGSD Vol 2 (1) Universitas Ganesha.

[5] Pusporini, A. \&. (2012). Pembelajaran Kimia Berbasis Problem Solving Menggunakan Laboratorium Rill dan VIrtual Ditinjau dari Gaya Belajar dan Kemampuan Berpikir Kritis Siswa. Jurnal Inkuiri, $34-43$. 
[6] Dewi, A. K. (2016). Pengaruh Model Pembelajaran GIPS terhadap kemampuan berpikir kritis dan Hasil Belajar Materi Hidrolisis. JIPS Vol 7 No. 2, 95 - 102.

[7] Lailatun Nadiah, M. A. (2017). Pengaruh Model Pembelajaran Peer Led Guided Inquary (PLGI) Terhadap literasi Sains dan Hasil Belajar Siswa Pada Materi Hidrolisis Garam Siswa XI SMA Negeri 3 Banjarmasin. JCAE , 73 85.

[8] Cathrine Benetuau, g. f. (2016). Peer Led Guided Inquary in Calculus at the Universitas California. Journal STEM Education vol 2, 5.

[9] Zawadki. (2010). Is Process Oriented Guided Inquiry Learning (POGIL) Suitable as a Teaching Method in Thailand's Education. Asian Journal on Education and Learning, 66 - 74 .

[10] Fagen, A. P. (2002). Peer Instruction:Result from a Range of Classroom,. Cambridge: Harvard University.

[11] Kurniawati, I. d. (2014). Pengaruh Pembelajaran Inkuiri Terbimbing Integrasi Peer Instruction Terhadap Penguasaan Konsep Dan Kemampuan Berpikir Kritis Siswa. Jurnal Pendidikan Fisiska Indonesia, 10: 36 - 46.

[12] Anderson, T. H. (2001). Peer Interaction And The Learning Of Critical Thingking Skills In Futher Education Students. ISJ 29: 1-23.

[13] Nicol, D. J. (2003). Peer Instruction Versus Class-wide Discussion in Large Classes: A comparasion Of Two Interaction Methods In The Wired Classroom . Center for Academic Pratice, University of Strathclyde. Studies in Higher Education , 28(4):457-473.
[14] Rahayu, A. P. (2014). Pembelajaran Kimia Menggunakan Metode Eksperimen dan Guided Inquiry dari Kemampuan Matematis dan Kreativitas Siswa . Jurnal Inkuiri, 96-107.

[15] Sukirmawati, J. W. (2013). Pembelajaran Biologi Dengen Guided Inquiry Model Menggunakan LKS Terbimbing dan LKS Bebas Termodifikasi Ditinjau dari Kreativitas dan Motivasi Berprestasi Siswa. Jurnal Inkuiri, 154 - 162.

[16] Raehanah, S. M. (2014). Pembelajaran Kimia Menggunakan Model Problem Solving Tipe Search Solve Create And Share (SSCS) dan Cooperative Problem Solving (CPS) Ditinjau dari Kemampuan Berpikir Kritis dan Kemampuan Matematis. Jurnal Inkuiri , 19 - 27.

[17] Kitot, A. A. (2010). The Efectiveness of Inquiry Teaching in Enhanching Student's Critical Thingking Universitas Kebengsaan Malaysia.

[18] Ardiyati, D. (2010). Pengaruh Pembelajaran Biologi Menggunakan Metode Problem Solving dan Metode Proyek Ditinjau dari Keingintahuan Siswa dan Keterampilan Berpikir Kritis Siswa. Surakarta: Tesiss Prodi Sains UNS.

[19] Facione. (2013). Critical Thinking: What It is and Way It Counts. California: California Academic Press.

[20] Chijoke, U. d. (2013). Determination of The Analytical Skilll Level Of Secondary Scholl Chemistry Students in Imo States Of Nigeria . Universal Journal of Education and Generalk Studies , 2(10): 336 - 356. 
[21] Yamin, M. (2009). Strategi Pembelajaran Berbasis Kompetensi. Jakarta: Gaung Persada Press.

[22] Fajri, L. d. (2015). Pembelajaran Hidrolisis Garam Menggunakan Model Inkuiri Terbimbing dan Proces Oriented Guided Inquiry Learning (POGIL) Ditinjau Dari Kemampuan Analisis Dan Rasa Ingin Tahu . Jurnal Inkuiri, 10-18.

[23] Depdiknas. (2008). Pengembangan Perangkat Penilaian Afektif. . Jakarta : Direktorat Pendidikan Menengah Umum Depdiknas.

[24] Durotulaila, A. H. (2014). Pengaruh Model Pembelajaran REACT (Realitng, EXperiencing, Applying, Cooperating, Transfering) Dengan Metode Eksperimen dan penyelesaian masalah terhadap prestasi belajar di tinjau dari kemampuan analisis. Jurnal Pendidikan Kimia (JPK), Vol 3 No 4, 68.

[25] Sayekti, I. C. (2012). Pembelajaran IPA menggunakan Pendekatan Inkuiri Terbimbing Melalui Metode Eksperimen dan Demonstrasi Dirtinjau dari Kemampuan Analisi dan Sikap IImiah Siswa. Jurnal Inkuiri, 142 - 153.
[26] Thamasena, b. (2009). Cognitive Development, Analytical Thingking and Learning Satisfaction of Second Grade Student Learned Through Inquiry Based Learning . Asian social science.

[27] Rusmiati, S. d. (2013). Pembelajaran Kimia Menggunakan Metode Learning Cycle 7E Dan Guided Inquiry Ditinjau Dari Kemampuan Berpikir Kritis Dan Kreativitas Siswa. Jurnal Inkuiri .

[28] Rustaman, N. (2007). Strategi Belajar Mengajar Biologi . Malang: Universitas Negeri Malang.

[29] Trisnawati, E. S. (2013). Pembelajatan Biologi Dengan Guided Inquiry Model Menggunakan Teknik Mind Map dan Concept Map Ditinjau dari Kemampuan Memori dan Motivasi . Jurnal Inkuiri. 